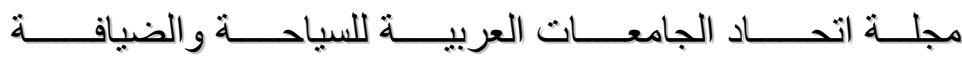

\title{
The Effect of Organizational Culture on
}

\section{Individual Outcomes in the Hotels Industry An application to $5 \& 3$ star hotels in Cairo}

\author{
Nagwa M. Ghorab \\ Faculty of Tourism \& Hotels \\ Menoufia University
}

\author{
Jehan El Amir Abbas \\ Faculty of Tourism \& Hotels \\ Menoufia University
}

\author{
Emad M. Abd El Aal \\ Faculty of Tourism \& Hotels \\ Menoufia University
}

\begin{abstract}
:
Organizational culture is significant and important because it helps hotels predict the behavioral intentions of their employees, and consequently assure their job satisfaction. Also understanding hotel culture facilitates the person and the organization fit which allows more consistency between employees and their work environment.
\end{abstract}

This paper investigates the relationship between some dimensions of organizational culture and satisfaction and behavioral intentions of front desk employees in 5 and 3 star hotels in Cairo in addition to studying the relationship between demographic variables of 5 and 3 star hotel samples and job satisfaction.

The main criterion for the selection of front desk employees is that they are in direct contact with guests all the time which brings them to physical and nervous tension and dissatisfaction so, hotels should adopt some culture that appeals to this segment of employees.

The main result was that valuing ethics, honesty, support for employees, fair compensation and employee development including promotion from within are the most critical dimensions of hotel culture that influence employees behavior. To enhance the results of this paper, hotel managers should compensate their employees fairly and develop training programs. Recruitment and selection process should be based on hotel culture and values to potentially increase job satisfaction and intention to stay in job.

Key words:

Organizational culture; Job satisfaction; behavioral intentions. Introduction:

An organization can be as effective as its people, especially for hotels that are characterized by continual and intense customer-staff contact. So customer contact employees have a tremendous impact on customer's perceptions of service quality and on customer satisfaction (Bitner et al., 1990; Heskett et al., 1994; Groves et al., 1995).For example, Brown et al. (2002) indicated that employees customer orientation is central to a service organization's ability to be market oriented . Furthermore, they suggested that organizational culture has a significant impact on overall service performance and at the organizational level influences the level of employee's job satisfaction, organizational commitment and business performance (Lee et al. 1999). 


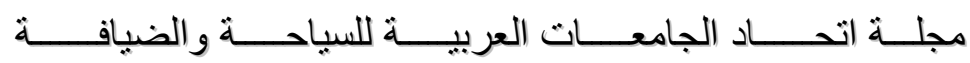

As early as the 1920s researchers realized that a relationship existed between the management styles of superiors and the job satisfaction of subordinates. By the late 1950s it was generally accepted that the levels of employee job satisfaction were higher in participative organizations than in autocratic organizations. Likert (1961) referred that the result of strict autocratic management is that the subordinate employee feels little responsibility toward organizational goals and often welcome the opportunity to undermine the organization. (Vallen, 1993).

Objectives:

The present study was conducted in order to:

1- Provide an explanation about the relationship between the hotel culture and job satisfaction, and behavioral intentions of its employees.

2- Investigate whether or not the hotel culture works as a predictor of employees behavioral intentions(leave / stay).

3- Explains whether or not the demographic variables affect job satisfaction of hotel employees.

Research Hypotheses:

Hypothesis 1:There is no significant relationship between the organizational culture (independent variable) and the two dependant variables (i.e. job satisfaction and behavioral intentions) when applied to 5-star and 3-star hotels.

Hypothesis 2: There is no significant difference between 5-star and 3-star hotels regarding the dependant variables.

Hypothesis 3:There is no significant relationship between the demographic variables and job satisfaction.

Review of literature:-

Despite the increasing interest and industry discussion about the importance of organizational culture, there is no consensus about what the term means exactly. Considerable agreement regarding the key elements and dimensions of organizational culture includes those of sharing meanings, norms, values and beliefs (Denison, 1996). Also culture is defined as the dynamic set of assumptions, values and artifacts that are collectively shared in a given society at a particular point in time (Hatch, 1993).

(1) Organizational culture:-

Organizational culture is defined as the values members of an organization share.

This is because their shared values are relatively stable, enduring and interact with 


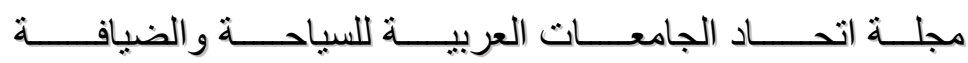

a company's people and organizational structure to produce patterns of behavior (Chatman, 1991).

Hill and Jones, (1998) define organizational culture as a specific collection of values and norms that are shared by people and groups in an organization and that control the way they interact with each other and stakeholders outside the organization.

Organizations do not possess value apart from the values of their members. Thus, an organizational value system is said to exist when individuals know that group support for a given belief exists, a majority of active members are in agreement, and the core values of an organization are intensely held throughout the organization (Chatman, 1991; Gordon and Tomasso, 1992).

(2) Job satisfaction:-

Job satisfaction is defined as a positive or negative evaluative judgment of one's job (Weiss, 1996). It is also the extent to which a worker feels positively or negatively to word his or her job, it refers to the employees' general effective evaluation of their job. In hospitality industry, job satisfaction helps to ensure that employees will treat customers with the utmost respect (Arnett et al., 2002).

Because of the importance of customer contact, employee's job satisfaction is a primary concern for hospitality organizations that rely up on loyalty. So job satisfaction leads to good employee performance that makes them less likely to leave.

\section{(3) Behavioral intentions :-}

Behavior is any thing a person does, feels, thinks or experiences. Intention of leaving is an important outcome in the behavior of hotel employees. Although intention of leaving is an undesirable outcome for organizations, it is valuable to understand its predictors in order to minimize its negative impact on organization's effectiveness (Low et al., 2001). To reduce the turnover rate in the hospitality industry, the firm must be sensitive to the intrinsic motivational factors of employees.

Exploring the organizational characteristics on employees' intent to quit could easily help hotel managers decrease actual employee turnover, the result could include improvements in customer service, employee productivity, and organization profitability.

\section{$\underline{\text { Research Methodology }}$}




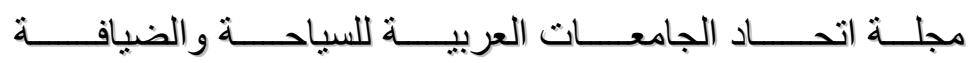

This research examines the influence of hotel culture and values on employees satisfaction and behavioral intentions between two categories of hotels (5-star and 3-star hotels) in Cairo. A questionnaire form has been distributed, data have been analyzed by using SPSS (descriptive statistics, ANOVA). Regression analysis was used to examine the relationship between the independent variables and the two dependent variables measured. Likert scale (ranging from 1 being strongly disagree to 5 being strongly agree) has been used when asking respondents to rank their perceived hotel culture dimensions which come as an independent variable in this study.

Sample and data collection: The sample that completed the questionnaire included 120 front desk employees in 5 \& 3 star hotel in Cairo, 40 questionnaire forms were lost and another 20 forms were invalid statistically. As a result of that 60 forms last appropriate for analysis with a percentage of $50 \%$ for 5-star hotels and alike for 3-star hotels.

Regarding the characteristics of the sample the percentage of males was $55 \%$ in 5 star hotel sample while it was $60 \%$ in 3-star hotels, females sample was $45 \%$ in 5 star hotels and $40 \%$ in 3-star hotels. In respect to the average age, it was approximately 35years for $5 \& 3$ star front desks employees. The majority of people working in front desk were married, tenure was 13-15years for 5-star employees while it was (6-9years) for 3-star hotel employees. Concerning the educational level, 5-star employees hold BSc, 3-star hotel employees working in front desks may have high School degree only, average working hours per week were 35hours for front desk employees of 5-star hotels, while 30 hours of working were the average for their counterparts in 3-star hotels.

These data were collected during the summer of 2006.

Results and discussion :

For better presentation, the obtained results would be discussed as follows:

Hypothesis 1:

1- The 5 star hotel sample

General Linear Model

Table 1. ANOVA

\begin{tabular}{|l|l|l|l|l|l|l|}
\hline Source & Dependent Variable & $\begin{array}{l}\text { Type 1 Sum } \\
\text { of Squares }\end{array}$ & df & $\begin{array}{l}\text { Mean } \\
\text { square }\end{array}$ & F & Sig. \\
\hline Organizational & Job Satisfaction & $\mathbf{3 0 6 8 . 3 0 5}$ & $\mathbf{1}$ & $\mathbf{3 0 6 8 . 3 0 5}$ & $\mathbf{9 5 7 . 4 1 0}$ & $\mathbf{. 0 0 0}$ \\
\hline \hline
\end{tabular}




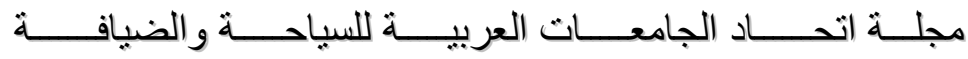

\begin{tabular}{|l|l|l|l|l|l|l|}
\hline \hline Culture & $\begin{array}{l}\text { Behavioral } \\
\text { Intention }\end{array}$ & 200.954 & 1 & 200.954 & 123.943 & .000 \\
\hline
\end{tabular}

2- The 3 star hotel sample:

General linear Model

Table 2. ANOVA

\begin{tabular}{|l|l|l|l|l|l|l|}
\hline Source & Dependent Variable & $\begin{array}{l}\text { Type } \\
\text { Sum of } \\
\text { Squares }\end{array}$ & df & $\begin{array}{l}\text { Mean } \\
\text { square }\end{array}$ & F & Sig. \\
\hline $\begin{array}{l}\text { Organizational } \\
\text { Culture }\end{array}$ & $\begin{array}{l}\text { Job. Satisfaction } \\
\text { Behavioral } \\
\text { Intention }\end{array}$ & 2752.237 & 1 & 2752.237 & 314.737 & .000 \\
& 228.138 & 1 & 228.138 & 113.617 & $\mathbf{. 0 0 0}$ \\
\hline
\end{tabular}

The results of analysis of variance have indicated that organizational culture has a significant influence on job satisfaction and behavioral intentions as the calculated $F$ values for these variables were found to be highly significant at $1 \%$ level of significance . Not surprisingly that thes strong evidence supports the linkage of employee satisfaction with customer satisfaction and organizational culture, in service organizations in general and specifically in hospitality (Hallowell et al., 1996 ; O’Reilly, 1991; Testa et al., 1998).

\section{Hypothesis 2:}

Table 3. Descriptive statistics

\begin{tabular}{|l|l|l|l|l|l|}
\hline \multicolumn{2}{|l}{} & N & Mean & $\begin{array}{l}\text { Std. } \\
\text { Deviation }\end{array}$ & Std. Error \\
\hline $\begin{array}{l}\text { Job } \\
\text { Satisfaction }\end{array}$ & 3 star hotel & 30 & 9.2000 & 2.10746 & .38477 \\
& 5 star hotel & 30 & 10.4000 & 1.81184 & .33079 \\
& Total & 60 & 9.8000 & 2.04027 & .26340 \\
\hline Behavioral & 3 star hotel & 30 & 2.8333 & 1.26173 & .23036 \\
Intentions & 5 star hotel & 30 & 2.6333 & 1.15917 & .21163 \\
& Total & 60 & 2.7333 & 1.20545 & .15562 \\
\hline
\end{tabular}

It is important to mention that these values exceeded their standard error.

Table 4. ANOVA

\begin{tabular}{|l|l|l|l|l|l|l|}
\hline \multicolumn{2}{|l|}{} & $\begin{array}{l}\text { Sum of } \\
\text { Squares }\end{array}$ & df & $\begin{array}{l}\text { Mean } \\
\text { square }\end{array}$ & F & Sig. \\
\hline Job. Satisfaction & Between Groups & 10.417 & 1 & 10.417 & 7.122 & .010 \\
\hline \hline
\end{tabular}




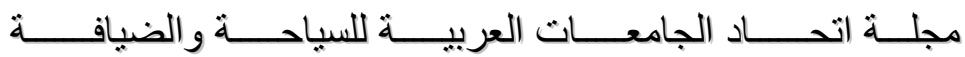

\begin{tabular}{|l|l|l|l|l|l|l|}
\hline \hline $\begin{array}{l}\text { Behavioral } \\
\text { intentions }\end{array}$ & Between Groups & .600 & 1 & .600 & .409 & .525 \\
\hline
\end{tabular}

The obtained results indicated that there is highly significant differences between 5 and 3 star hotels concerning job satisfaction, more over, the job satisfaction in 5 star hotels was found to be higher than that in 3-star hotels, because the performance of the 5 star hotels is higher than that of the 3 star hotels.

Also there is no significant differences between the 5 and 3 star hotels concerning behavioral intentions (leave / stay).

\section{Hypothesis 3:}

1-The 5 star hotel

Regression :

Table 5. Model summary

\begin{tabular}{|c|c|c|c|c|}
\hline Model & $\mathbf{R}$ & R Square & $\begin{array}{l}\text { Adjusted R } \\
\text { Square }\end{array}$ & $\begin{array}{l}\text { Std. Error of the } \\
\text { Estimate }\end{array}$ \\
\hline $\begin{array}{l}\text { Tenure with the } \\
\text { hotel }\end{array}$ & $.450^{\mathrm{a}}$ & .203 & .174 & .98204 \\
\hline Educational level & $.565^{\mathrm{b}}$ & .319 & .269 & .92390 \\
\hline Age & $.646^{\mathrm{c}}$ & .418 & .350 & .87098 \\
\hline
\end{tabular}

Table 6. Model summary

\begin{tabular}{|l|l|l|l|l|l|}
\hline \multirow{2}{*}{ Model } & \multicolumn{3}{|l|}{ Change Statistics } \\
\cline { 2 - 6 } & $\begin{array}{l}\text { R Square } \\
\text { Change }\end{array}$ & F Change & df1 & df2 & $\begin{array}{l}\text { Sig. F } \\
\text { Change }\end{array}$ \\
\hline $\begin{array}{l}\text { Tenure with the } \\
\text { hotel }\end{array}$ & .203 & 7.117 & 1 & 28 & .013 \\
$\begin{array}{l}\text { Educational level } \\
\text { Age }\end{array}$ & .117 & 4.635 & 1 & 27 & .040 \\
\hline
\end{tabular}

Table 7. ANOVA

\begin{tabular}{|c|c|c|c|c|c|}
\hline \multicolumn{2}{|l|}{ Model } & df & $\begin{array}{l}\text { Mean } \\
\text { Square }\end{array}$ & $\mathbf{F}$ & Sig. \\
\hline Tenure with the hotel & $\begin{array}{l}\text { Regression } \\
\text { Residual } \\
\text { Total }\end{array}$ & $\begin{array}{l}1 \\
28 \\
29\end{array}$ & $\begin{array}{l}6.864 \\
.964\end{array}$ & 7.117 & $.013^{\mathrm{a}}$ \\
\hline
\end{tabular}




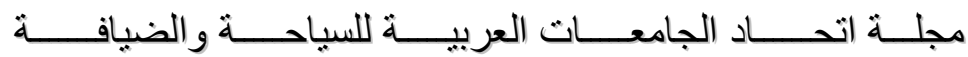

\begin{tabular}{|l|l|l|l|l|l|}
\hline Educational level & Regression & 2 & 5.410 & 6.338 & $\mathbf{. 0 0 6}^{\mathbf{b}}$ \\
& Residual & 27 & .854 & & \\
Total & 29 & & & \\
\hline Age & Regression & 3 & 4.714 & 6.215 & $\mathbf{. 0 0 3}^{\text {c }}$ \\
& Residual & 26 & .759 & & \\
& Total & 29 & & & \\
\hline
\end{tabular}

Table 8. Coefficients

\begin{tabular}{|l|l|l|}
\hline \multirow{2}{*}{ Model } & $\begin{array}{l}\text { Unstandardized } \\
\text { Coefficients }\end{array}$ & \multirow{2}{*}{ Sig. } \\
\cline { 2 - 2 } & B & \\
\hline (Constant) & 8.761 & .000 \\
Tenure with the hotel & .360 & .013 \\
\hline (Constant) & 6.144 & .000 \\
Tenure with the hotel & .294 & .033 \\
Educational level & .815 & .040 \\
\hline (Constant) & 4.098 & .022 \\
Tenure with the hotel & .315 & .017 \\
Educational level & .917 & .017 \\
Age & .406 & .046 \\
\hline
\end{tabular}

2-The 3 star hotel

Regression :

Table 9. Model summary

\begin{tabular}{|l|l|l|l|l|}
\hline Model & $\mathbf{R}$ & R Square & $\begin{array}{l}\text { Adjusted } \\
\text { R Square }\end{array}$ & $\begin{array}{l}\text { Std. Error of } \\
\text { the Estimate }\end{array}$ \\
\hline Gender & $\mathbf{. 5 7 6}^{\mathbf{a}}$ & $\mathbf{. 3 3 1}$ & $\mathbf{. 3 0 7}$ & $\mathbf{1 . 6 2 5 6 9}$ \\
Tenure with the hotel & $\mathbf{. 6 5 0}^{\mathbf{b}}$ & $\mathbf{. 4 2 2}$ & $\mathbf{. 3 8 0}$ & $\mathbf{1 . 5 3 8 6 8}$ \\
\hline
\end{tabular}

Table 10. Model summary

\begin{tabular}{|l|l|l|l|l|l|}
\hline \multirow{2}{*}{ Model } & \multicolumn{4}{|l|}{ Change Statistics } \\
\cline { 2 - 7 } & $\begin{array}{l}\text { R Square } \\
\text { Change }\end{array}$ & F Change & df1 & df2 & $\begin{array}{l}\text { Sig. F } \\
\text { Change }\end{array}$ \\
\hline Gender & .331 & 13.874 & 1 & 28 & .001 \\
Tenure with the hotel & .091 & 4.256 & 1 & 27 & .049 \\
\hline
\end{tabular}




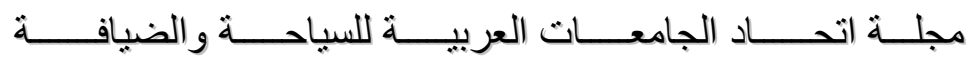

Table 11. ANOVA

\begin{tabular}{|l|l|l|l|l|l|}
\hline \multicolumn{2}{|l|}{ Model } & df & $\begin{array}{l}\text { Mean } \\
\text { Square }\end{array}$ & F & Sig. \\
\hline Gender & $\begin{array}{l}\text { Regression } \\
\text { Residual } \\
\text { Total }\end{array}$ & $\begin{array}{l}1 \\
28\end{array}$ & $\begin{array}{l}36.667 \\
2.643\end{array}$ & 13.874 & $.001^{\text {a }}$ \\
\hline $\begin{array}{l}\text { Tenure with the } \\
\text { hotel }\end{array}$ & $\begin{array}{l}\text { Regression } \\
\text { Residual } \\
\text { Total }\end{array}$ & 27 & 29 & & \\
& 29 & 2.368 & & \\
\hline
\end{tabular}

Table 12. Coefficients

\begin{tabular}{|l|l|l|}
\hline \multirow{2}{*}{ Model } & $\begin{array}{l}\text { Unstandardized } \\
\text { Coefficients }\end{array}$ & \multirow{2}{*}{ Sig. } \\
\cline { 2 - 2 } & B & \\
\hline (Constant) & 5.000 & .000 \\
Gender & 2.500 & .001 \\
\hline (Constant) & 7.249 & .000 \\
Gender & 2.210 & .002 \\
Tenure with the hotel & -.448 & .049 \\
\hline
\end{tabular}

Stepwise regression analysis has indicated that the following independent demographic variables have succeeded in the prediction of employees job satisfaction as follows:

* 5-star sample

1- Tenure with the hotel : contributed by $20 \%$ to the prediction of job satisfaction.

2- Educational level : contributed by $11 \%$ to the prediction of job satisfaction.

3- Age : contributed by $9 \%$ to the prediction of job satisfaction.

* 3-star sample

1- Gender : contributed by $33 \%$ to the prediction of job satisfaction.

2- Tenure with the hotel : contributed by $9 \%$ to the prediction of job satisfaction.

Concerning gender, the prediction was more positive for men than women. There was also negative prediction of job satisfaction, if the length of work increases, employees are likely to be less satisfied and intend to leave the hotel.

\section{Conclusion:}




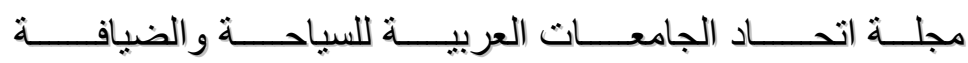

The effect of organizational culture obviously existed for the individual outcomes of front office employees, where analysis of variance has indicated that organizational culture elements of valuing ethics and honesty, fair compensation and promotion from within have a significant influence on job satisfaction and behavioral intentions as the calculated $F$ values for these variables were highly significant at $1 \%$ level of significance.

There are highly significant differences between 5 and 3 star hotels concerning job satisfaction, moreover, the job satisfaction in 5 star hotels was found to be higher than that in 3-star hotels, because the performance of the former is higher than in the latter.

The following independent demographic variables have succeeded in the prediction of employees' job satisfaction as follows:

5-star hotels sample

- Tenure with the hotel: contributed by $20 \%$ in the prediction of job satisfaction.

- Educational level: contributed by $11 \%$ in the prediction of job satisfaction.

- Age: contributed to $9 \%$ by the prediction in job satisfaction.

3-star hotels sample

- Gender: contributed by $33 \%$ in the prediction of job satisfaction.

- Tenure with the hotel: contributed by $9 \%$ in the prediction of job satisfaction.

Concerning gender, the prediction was positive for men than women. There was also negative prediction of job satisfaction, if the lengths of work increases, employees are likely to be less satisfied and intend to leave the hotel.

\section{$\underline{\text { Recommendation }}$}

To enhance the results of this paper, hotels management should:

- Recruit and select on the basis of hotel culture and values to potentially increase job satisfaction and intention to stay in job.

- Compensate their employees fairly.

- Develop training programs to improve employees' loyalty. 


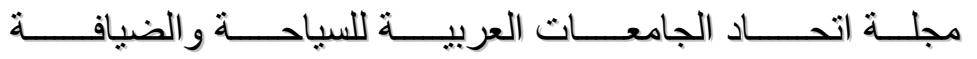

- Promote employees' from within.

- Adopt values that appeal to the employees. 


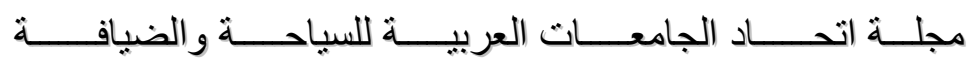

\section{References}

1.Arnett, D. Laverie, D. , Mclane C., (2002) Using job satisfaction and pride as internal marketing tools, Cornell Hotel and Restaurant Administration Quarterly 43 (2), pp.87-96.

2.Bitner, M., Booms, B., Tetreault, M., (1990) The service encounter : diagnosing favorable and unfavorable incidents, Journal of marketing, 54 (January),pp. 71-84.

3.Brown, S., Mowen, J., Donava, D., Licata, J., (2002) The customer orientation of service workers: personality trait effects on self and supervision performance rating, Journal of Marketing Research (34) ,pp. 110-119.

4.Cable, D., and Judge, T., (1994) Pay references and job search decisions : a person - organization fit perspective, Personnel Psychology, 47,pp.317-348.

5.Chatman, J.A., (1991) Matching people and organizations: selection and socialization in public accounting firms, Administrative Science Quarterly, 36,pp. 459-484.

6.Denison, D., (1996) What is the difference between organizational culture and organizational climate? A native's point of view, Academy of Management Review, 21,pp.619-54.

7.Gordon,G., and Tomasso, N., (1992) Predicting corporate performance from organizational culture, Journal of Management Studies, 29 , 6 ,pp. 783-98.

8.Groves, J., Gregorie, M., Downey, R.,(1995) Relationship between the service orientation of employees and operational indicators in a multiunit restaurant corporation, Hospitality Research Journal, 19(3), pp.33-43.

9.Hallowell, R., Schlesinger, L., \& Zornitsky, J., (1996) Internal service quality, customer and job satisfaction, Human resource planning, 19 (2), pp.20-31.

10. Hatch, M., (1993) The dynamics of organizational culture, Academy of Management Review, 18(4),pp.657-93.

11. Heskett, J., Jones, J., love man, G., Sasser, W., (1994) Putting the service profit chain to work, Harvard Business Review, 27(2),pp. 164-174. 


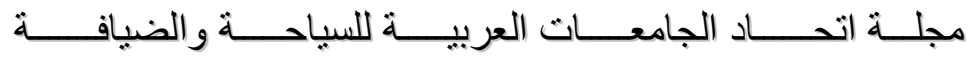

12. Hill, C., and Jones, G., (1998) Strategic management theory : An Integrated Approach, New York, Fourth edition Houghton company , p.396.

13. Huffman, K., Vernoy, M., and Vernoy, J., (1994) psychology in action, John Wiley and Sons .

14. Likert, R., (1961) New patterns of Management, New York McGraw Hill, p.3.

15. Low, G., Cravens, D., Grant, K., Moncrief, W., (2001) Antecedents and consequences of salesperson burnout, European Journal of Marketing 35(5/6),pp.587-614.

16. O'Reilly, C.A., (1991) People and organizational culture, Academy of Management Journal, 34(3),pp. 487-516.

17. Testa, M, Skaruppa, C., Pieterzak, D., (1998) Linking job satisfaction and customer satisfaction in the cruise industry, Journal of Hospitality and Tourism Research 22(1),pp. 4-14.

18. Vallen, G.K., (1993) Organizational climate and burnout, Cornell Hotel and Restaurant Administration Quarterly, 34 (1), pp.54-59.

19. Weiss, H.M., (1996), A theoretical discussion of the structure, causes, and consequences of effective experiences at work Organizational Behavoir, 18, pp.1-74. 
أثر ثقافة المنظمة على سلوك العاملين في صناعة الفنادق بالتطبيق على الفنادق ذات الخمس والثلاث نجوم في القاهرة

تقـاس كفـاءة المنظمسة بكفـاءة العـاملين فيها، هذا القول يعتبر حقيقيـا في صـناعة

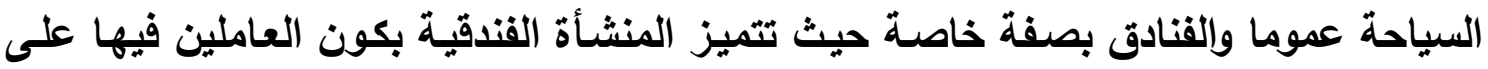
اتصـال مستمر ومباثر بالنزلاء كما أن العلاقات بين جميع أطرافها تثبير إلى التأثير الفعال

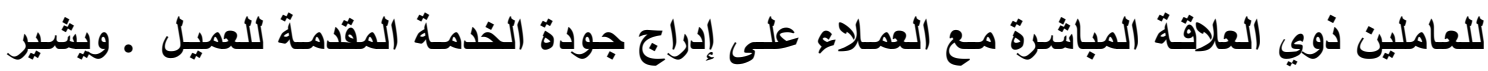

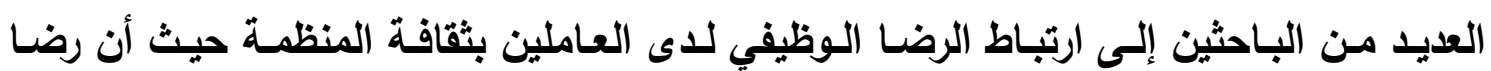

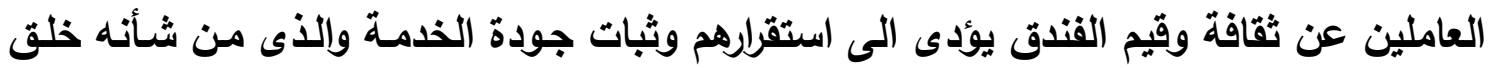
ولاء النزلاء للقندق وزيادة ريحيته على المدى البعيد.

يهدف البحث إلى دراسة اثر ثقافة المنظمة (الفندق) على سلوك العاملين المتعلق بنية ترك الوظيفة أو الاستمرار فيها كما يهدف إلى دراسـة العلاقة بين العوامل الديموجرافية والرضا الوظيفي.

أظهرت نتائج الدراسة وجود تأثثر معنوي قوي بين ثقافة المنظمة ورضا العاملين وكذلك

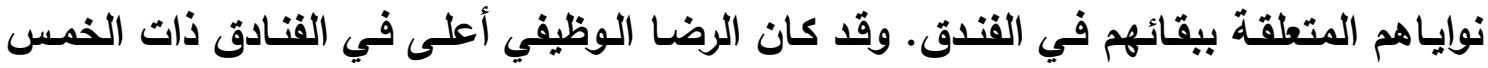
نجوم عنه في الفنادق ذات الثلاث نجوم، وجد أن المتغيرات الديموجرافية المتمثلة في طول فترة

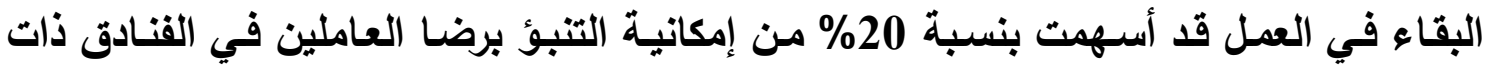
الخمس نجوم مقابل 9\% في الفنادق ذات الثلاث نجوم، كما سـاهم مستوى التعليم في إمكانية التهاتية التنبؤ برضا العاملين بنسبة 11\% في الفنادق ذات الخمس نجوم أما العمر فقد ساهم في التنبؤ

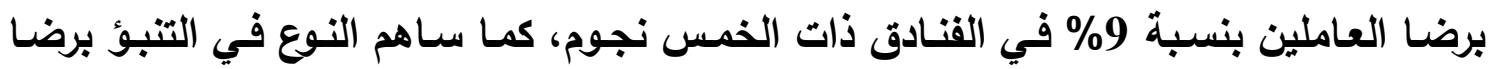

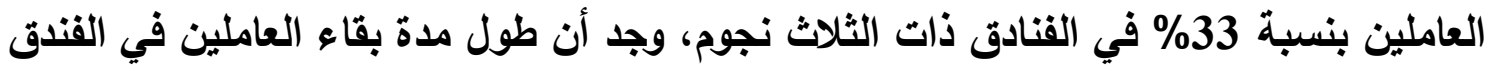

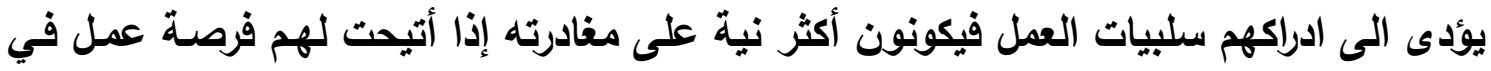

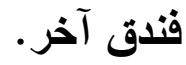




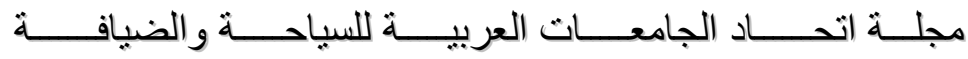

Questionnaire

Part1 : demographic questions asked here will be used only for statistical analysis purposes.

1- are you?

Male

Female.

2- what is your age ?

3- how long have you been working for your current hotel ?

what is your level of education?

Part 2: Please circle the number on the scale as each question represents your feeling about your current hotel!

1- In general, I don't like working here .

2- My values match those of this hotel .

3- My values match those of co-workers .

4- Despite all things, I like my job .

5- I intend to remain with this hotel .

6- I have thought seriously about changing this hotel since I have worked here. 
Part 3: About your hotel's culture and values, please circle the number that describes these values.

No. Item

1- Emphasis on service quality .

2- $\quad$ Promotion from within .

3- Support for employees .

4- Paying attention to details .

5- Valuing ethics and honesty .

6- Risk taking when application of new ideas.

7- Fair compensation .

8- Team atmosphere .

9- $\quad$ Training is important .

10- Valuing customers .
Disagree Neutral Agree

1

23

$\begin{array}{lll}1 & 2 & 3\end{array}$

$1 \quad 2 \quad 3$

123

123

1

23

1

23

1

23

1

23

1

2

3 